\title{
CASE STUDY ON THE BIOPSYCHOSOCIAL IMPACTS AND COPING BEHAVIORS AMONG VICTIMS OF FEMALE SEXUAL VIOLENCE IN SUKOHARJO, CENTRAL JAVA
}

\author{
Isna Rahmawati Retnaningsih ${ }^{1)}$, Argyo Demartoto²), Eti Poncorini3) \\ 1)Masters Program in Public Health, Sebelas Maret University \\ 2)Department of Political and Social Science, Sebelas Maret University \\ 3)Department of Public Health, Faculty of Medicine, Sebelas Maret University
}

\begin{abstract}
Background: Sexual violence on women is a serious social problem. It may cause various impacts including biological, reproductive, psychological, and social impacts. There is a need for behavioral change to deal with the impact of sexual violence. This study aimed to explore the biopsychosocial impacts and coping behaviors among female sexual violence victims.

Subjects and Method: This was a qualitative descriptive research using case study method. The study was conducted in Sukoharjo from 15 June to 25 July 2017. Key informants were included female sexual violence victims and close persons, Chairman of NGO Alliance of Concern in Women's Welfare (APPM), volunteers of One Heart Disability Society, staff of Office for Women's Empowerment, and Head of Women and Child Protection Unit, and medical personnel. The data were collected by in-depth interview, observation, and document review. Interactive analysis included data collection, reduction, display, and verification.
\end{abstract}

Results: The age of female victims of sexual violence ranged between 15 and 21 years. They had no schooling or junior high school education. All of them came from Sukoharjo, Central Java. The forms of sexual violence were sexual harassment and rape. The perpetrators were close persons of the victim. The biological, reproductive, and psychological impacts of the victim included fear, irritation, trauma, worry, self-imprison, self-contain, feelings of revenge, emotion, stress, pain during urination, fever, unwanted pregnancy, and complications of childbirth. The social impacts included isolation, gossiping, and negative stigma of the victim. The victim's behaviors in coping with the biopsychosocial impacts included routine medical check up, attempt to forget, taking for granted, and avoidance of bringing up the incidents of sexual violence, preoccupation with positive activities, seeking support of the close person, being more careful of the opposite sex, and avoidance of mingling with unrecognized people in a strange environment.

Conclusion: Female sexual assault cases suffered undesireable biological, reproductive, psychological, and social impacts. The impacts of biological and reproductive health take the forms of health problems, unwantted pregnancy, and complications of childbirth. There is a need for support to help overcome the biopsychosocial impacts of sexual violence victims.

Keywords: Health Belief Model, biopsychosocial impacts, sexual violence

Correspondence: Isna Rahmawati Retnaningsih. Masters Program in Public Health, Sebelas Maret University, Jl. Ir. Sutami 36 A, Surakarta 57126, Central Java. Email: rahmawatiisna.ir@gmail.com. Mobile: +6285640533107. 